\section{THE EVOLUTION OF COLOUR IN THE GENUS MEGASCOPS.}

THE American Naturalist of June and July contains an article by Mr. E. M. Hasbrouck on "Evolution and Dichromatism in the Genus Megascops," in which he deals with the distribution of the genus in North America in relation to the colour of its plumage. The discussion leads to the fol. lowing conclusions :-

"The red phase is confined mainly to Megascops asio (speaking of it as a whole), which, on its northern border, merges into the grey phase; the southern grey belt incompasses floridanus, while in eastern Texas the few red specimens of mecallii that are known have been taken from the extreme north-eastern portion of its range, which is influenced both by humidity and temperature. Again this distribution of colour corresponds very closely to the life areas-the grey phase of the Florida form in the south occupying a major portion of the Austroriparian; the red phase of asio proper conforming very closely to even the outlines of the Carolinian, while the grey phase is equally identical with the Alleghanian.

"It is worthy of note that the grey phase of Megascops asio is boreal in its alfinities, and that where a grey phase of asio is found that is not boreal, it is recognised as a sub-species.

"Now if floridanus (grey) is separable from asio just north of it (red), it seems highly probable that asio (red) will some day be separated from the grey phase on the north. It has been shown that as regards the two phases of asio, certain areas are inhabited exclusively by reds, certain ones exclusively by greys, while still others are inhabited by a mixture of the two, and that three forms (Aloridanus and two colour phases of asio proper inhabit, as a whole, entirely distinct areas. No one will deny that all of the forms of Mregizscops are descended from a common ancestor, and if through climatic or environmental conditions they have become sub-specifically differentiated in various iocalities, I see no reason to doubt that in like manner, under the influence of humidity, temperature, acquired character, and forest area, which will be felt for countless generations to come, that the species now known as Megascops asio will one day be separated into species and sub-species-the former represented by the original grey, and the latter by the more modern red.'

\section{UNIVERSITY AND EDUCATIONAL INTELLIGENCE}

The Medical Session began on Monday in the schools attached to the London and provincial hospitals. Dr. W. Pasteur delivered the introductory address at Middlesex Hospital, and Mr. Thomas Holmes at St. George's Hospital. The subject of Mr. Holmes's discourse was the life and works of John Hunter, being the centenary celebration of Hunter's death within the walls of the hospital. The address at St. Mary's Hospital was delivered by Mr. J. Ernest Lane, and at the London School of Medicine for Women by Miss Helen Webb. Biology and ethics formed the subject of the opening address delivered by Sir James Crichton Browne at the Sheffield School of Medicine.

Mr. Walter Garstang, of the Plymouth Marine Biological Laboratory, has been elected to a Research Fellowship by Lincoln College, Oxford.

THE first entrance scholarship to St. Thomas's Hospital Medical School, of the value of $£ 150$, has been awarded to $\mathrm{Mr}$. Robert Wynn Charles Pierce, and the second, of the value of $£ 60$, to Mr. Harry Edward Hewitt.

THE Entrance Scholarship, of the value of rzo guineas, to Charing Cross Hospital Medical School has been awarded to Mr. Harold A. T. Fairbank, and that of the value of 60 guineas to Mr. Stanley W. R. Colyer.

THE following entrance scholarships to Guy's Hospital have been awarded in science. First, of the value of $\oint_{150}$, to Philip Turner, University College, London; second, value $£ 60$, to George Ernest Richmond, Owens College.

THE Balfour Studentship, of the nett annual value of $£ 200$, will be vacant on October I8. From the regulations sanctioned by the Senate of the University of Cambridge, it appears that the studentship is not awarded upon the result of a competitive examination, and the student need not be a member of the Uni- versity. The holder of the studentship must devote himself, however, to original biological inquiry, and must not follow any business or profession, or engage in any educational or other work, which, in the opinion of those charged with the administration of the Balfour Memorial Fund, would interfere with his original inquiries.

Mr. W. TOWNSEND PORTER has investigated the relation between physical development and success in school life, his data for discussion being obtained fron 33,500 boys and girls in the public schools of St. Louis (Transactions of the Academy of Science of St. Louis, vol. vi. No. 7). The weight of a child can usually be taken as a trustworthy index of physical development, and, comparing it with standards of intelligence, it appears that precocious children are heavier, and dull children lighter than the average child of the same age. Not only is this the case, but precocious children are taller, have larger chests, and wider heads than dull children. An examination has also been made of the relationship between precocity and rate of growth, or yearly increase in size, and the results indicate that the difference in weight between dull and precocious boys increases as they grow older. The conclusions arrived at are based upon means and averages, and may not be applicable to individuals. However, one deduction of considerable importance is made. It is that no child whose weight is below the average of its age should be permitted to enter a school standard beyond the average of its age, except after such a physical examination as shall make it probable that the child's strength shall be equal to the strain.

\section{SCIENTIFIC SERIALS}

THE Meteorolouische Zeitschrift for July contains an account of observations taken at the Hawaiian Islands, communicated by Dr. Marcuse, of the Berlin Observatory, who for some time visited Honolulu for astronomical investigations. The position of those islands, near the northern limit of the tropical zone, is very important from a meteorological point of view, and the Hawaiian Government have for some years past established a regular service under Mr. C. J. Lyons, who publishes a monthly meteorological summary. The principal station is at Punahou (Oahu), a little to the north-east of $\mathrm{H}$ onolulu, on which island there are also sixteen other stations, also twenty-three stations on the island Hawaii, and fourteen on the other islands, making altogether a total of fifty-four, two of which are 4100 feet above sea-level. The oldest temperature observations date from the time of the first American mission in 1821 , and with some interruptions have been continued to the present time. From the more recent objervations the mean annual temperature is $74^{\circ} \cdot \mathrm{I}$. During the last ten years the lowest temperature was $54^{\circ} \circ$, and the highest $89^{\circ} \cdot \mathrm{I}$; the greatest daily variation being $23^{\circ}$. The warmest month is August, mean temperature $78^{\circ} \cdot 1$, and the coldest, January, mean $69^{\circ} \cdot 8$. Barometric pressure is very regular, the yearly period amounting to about 0.7 inch, and the daily period to 06 inch. The larger oscillations occur only when the almost regular northerly trade winds, which blow on an average for 258 days in the year, are replaced by southerly winds. The rainfall differs considerably in different parts of the islands; at Honolulu the mean of thirteen years' observations is $30^{\circ} 6$ inches. The largest amount falls between November and February; the dryest month is June, with about one inch.

August. - "Die neue Anemometer-und Temperatur-Station auf dem Obir-Gipfel," by J. Hann.-On the dynamics of the atmosphere, by M. Möller. This is a continuation of a series of valuable papers on the physics of the atmosphere. The present article deals chiefly with the behaviour of cyclones and anticyclones, and with the vertical distribution of temperature and aqueous vapour.

THE Botanical Gazette for August has an article on cell-union in herbaceous grafting, by $\mathrm{Mr}$. John S. Wright, in which the remarkable assertion is made that not only a geranium, but also Tradescautia zebrina has been successfully grafted on the tomato, that is, a monocotyledonous on a dicotyledonous plant. Mr. L. N. Johnson describes the mode of formation and escape of the little-known zoospores of Draparualdia plumosa.

THE numbers of the Fournal of Botany for August and September are chiefly occupied by papers on descriptive botany. Mr. H. T. Soppill gives an account of the life-history of Aicidium leucospermum, parasitic on Anemone nemorosa.

NO. I 249 , VOL. 48 ] 